\title{
Special Theme Introduction: Education and Outreach in Ecological Restoration
}

\section{James Aronson}

I $\mathrm{n}$ dozens if not hundreds of schools and universities today, from Australia and New Zealand to the Americas and several countries in Europe, Asia, and Africa, formal courses and full degree programs are emerging that address the science and the practice of ecological restoration. This is cause for celebration, since ecological restoration has much to offer in light of the urgent need for transition towards global sustainability.

The modern science and practice of restoration ecology-after 32 years, to borrow the age of SER International-have evolved to where they command respect from colleagues in fundamental ecology, conservation biology, environmental science, and various social sciences. Interest and engagement are growing as well among engineers, hydrologists, foresters, planners, architects, community leaders, business leaders, and professional environmental managers working with outdoor areas where new ideas and new paradigms are needed. What's more, ecological restoration is increasingly drawing attention from economists, lawyers, politicians, and other decisionmakers who, for better or worse, decide on policies, taxes, incentives, and overall budgets at regional, national, and international levels.

There aren't enough trained practitioners, teachers, and communicators, however, to fill all the posts that will be opening up in the coming years. In their recent study of 300 U.S. and Canadian academic institutions to determine whether current curricula in restoration can meet the needs of this growing field, authors Nelson, Schoennagel, and Gregory (2008) determined that opportunities to obtain a degree in the field of restoration are extremely limited. Only 11 institutions (4\%) offered undergraduate degrees, and only four (1\%) offered graduate degrees. In other continents and most other countries, even fewer educational opportunities exist. What to do? More teaching, of course, in workshops, semester-long courses, and outreach efforts in a wide range of contexts, not just in formal educational institutions.

In this special issue on education and outreach in ecological restoration, we bring together 12 articles and

Ecological Restoration Vol. 28, No. 2, 2010

ISSN 1522-4740 E-ISSN 1543-4079

(O2010 by the Board of Regents of the University of Wisconsin System.
Restoration Notes from four different continents, including six pieces from Latin America. The diversity of educational context and content reflected in these 12 pieces reveals the multiple ways that teachers are reaching out to audiences. The authors present instructive and inspiring examples of programs in a primary and secondary school in Monteverde, Costa Rica, and university level programs in Ecuador, the United States, and Spain. We also are pleased to offer a glimpse of a five-year-old, multiuniversity Master's program in Madrid, Spain, led by José-Maria Rey-Benayas.

From Australia, Dave Tongway writes about his widely recognized restoration workshops developed for land and livestock managers and others in southeastern Australia, but proven in the field in Papua New Guinea, Madagascar, and Spain as well. Tom Simpson reports on a successful adult restoration education program in Northeastern Illinois. We also have an exciting report from Bev Debrincat, whose organization in Sydney, Australia, has been doing community-based restoration, education, and outreach in the suburbs for the last ten years. From Colombia, yet another restoration veteran, Carolina Murcia, writes about the need for building in environmental education, conservation, and restoration programs, and in particular this time, teaching restoration workshops to busy national park managers who have no time for workshops. From further south on the same continent, another exceptional NGO, COOPLANTAR, reports on its program based in a poor farming district of southeastern Brazil.

There are also lively descriptions of education and outreach programs in Costa Rica, including that of the Organization of Tropical Studies research institute, Las Cruces, led by tropical restoration ecologists Zak Zahawi and Karen Holl. We learn about the network of teachers across the United States and Puerto Rico involved in the University of Wisconsin-Madison Arboretum's Earth Partnership for Schools program from Rick Hall and Cheryl BauerArmstrong. Marian Farrior, also of the U.W. Arboretum, shares tools from the social sciences that help her pursue restoration outreach. We also have a Restoration Note about the vast education program of the Área de Conservación Guanacaste, famous for the pioneering large-scale conservation and restoration work initiated there over 30 years ago by Daniel Janzen and Winny Halwachs.

All readers of this journal know that no two restoration sites are exactly alike, nor are the degrees or causes of ecosystem impairment and landscape fragmentation exactly 
the same. The articles gathered here in this special theme underscore the importance of teaching how every ecological restoration project must be tailored to suit biophysical, socioeconomic, and cultural conditions in a manner that satisfies project goals and motivations based on human values (Clewell and Aronson 2007). These contributions also illustrate that ecological restoration is something to teach and to learn not only in classrooms, but also in the field where actual restoration practice — and research — are taking place. Finally, the variety, breadth, and originality of these courses, workshops, and programs are clearly cause for celebration. Great things are happening out there to further education and outreach about ecological restoration.

\section{Acknowledgments}

I would like to thank Mrill Ingram for the invitation to organize this special issue, and for her help. It's been great fun. Assistant Editor Chris Reyes was wonderfully responsive, creative, and efficient too, despite a difficult personal context she was dealing with at the time. Thanks Chris. I am also grateful to everyone who contributed a piece of the puzzle, as they are all busy people who took time out to write up these reports and to work patiently and cheerfully, often at short notice. Finally, I thank my friends and colleagues Andy Clewell and Christelle Fontaine for their help on this and many other projects.

\section{References}

Clewell, A.F. and J. Aronson. 2007. Ecological Restoration: Principles, Values, and Structure of an Emerging Profession. Washington DC: Island Press.

Nelson, C.R., T. Schoennagel and E.R. Gregory. 2008.

Opportunities for academic training in the science and practice of restoration within the United States and Canada. Restoration Ecology 16:225-230.

James Aronson is head of the Restoration Ecology Group at the Center of Functional and Evolutionary Ecology, of the government research network (CNRS), in Montpellier, France. He is also Curator of Restoration Ecology at the Missouri Botanical Garden, USA. He can be reached at james.aronson@cefe.cnrs.fr; Centre d'Ecologie Fonctionnelle et Evolutive (CNRS-UMR 5175), 1919, Route de Mende, 34293 Montpellier, France, and through the RNC Alliance, www.rncalliance.org. 